\title{
Research on the Fairness of Income Distribution from the Perspective of Finance and Taxation Law
}

\author{
Jia Dong ${ }^{1, a}$ \\ ${ }^{1}$ Dianchi College of Yunnan University, Kunming, Yunnan 650228, China \\ adjsl1213@126.com
}

Keywords: Fiscal and taxation law; Income distribution; Fairness

\begin{abstract}
Fair income distribution affects the country's long-term stability and affects the stability of society. With the development of social economy, people's living standards are gradually improved, but at the same time, the income gap is widened, so the lower income groups will form a relative deprivation. Sense, the modern state through the fiscal and taxation policies to achieve the capture of social resources, through the way of public services to achieve the goal of fairness. The fiscal and taxation law emphasizes that it is taken from the civilian use of the people and ultimately achieves social fairness and justice.
\end{abstract}

\section{Introduction}

Fair income distribution means that social workers obtain corresponding social wealth through work. Social wealth is not concentrated in the hands of a few people, but social labor development results are shared by all social workers. Although China emphasizes common prosperity in economic development, China still faces a situation of widening income gap and serious imbalance in income.

\section{The Main Reason Affecting the Fairness of Income Distribution}

The income distribution policy is imperfect, and the income distribution reform lags behind. At present, China's income distribution policy orientation is not very clear. There is a gap in the reform of the income distribution system and the corresponding program design. From the overall planning, the policy of designing income distribution has not been able to be embodied in executable policy measures, especially In the regulation of income distribution policies in various regions, there are different situations in the degree of economic development and the indifference of wealth in various regions. Policies in some regions only play a role in a short period of time. They can increase the proportion of residents' income in national income and increase the proportion of labor compensation in the initial distribution. However, for redistribution, there is no corresponding quantitative standard in each region.

The social security policy is not perfect and cannot effectively regulate income distribution.

As far as the current situation of income distribution is concerned, there is a serious imbalance between urban and rural areas in China[1]. The rural economy is mainly based on agriculture, the city is dominated by the second and third industries, and the cities are superior to rural areas in terms of economic development efficiency and development results. China's social security system does not comprehensively cover urban and rural residents, and the social security between urban and rural residents is not perfect. The minimum living security of urban and rural residents in China is also lower than the world average, and due to regional differences, the differences in the design of social security indicators have seriously affected the income adjustment of the region.

Tax structure is unreasonable and the role of taxation cannot be exerted

The fiscal and taxation legal system is designed to regulate income distribution, but its structure is unreasonable, and the logic that is reflected will affect its expected role.[2] In the early stage of reform and opening up, China's taxation system focused on the role of taxation in national fiscal revenue. The emphasis here is on the state's ability to extract resources, but it ignores the taxation regulation of social income distribution and the promotion of social equity. It can be seen from the current types of tax collection that the business tax, value-added tax and consumption tax generally 
have a larger proportion of the total tax revenue, while the corresponding property tax and personal income tax have a smaller proportion in the entire tax revenue[3]. At the same time, the standard and structure of personal income tax also showed an unreasonable situation.

The economic reform is not thorough and the income distribution is unfair

In some industries, the income of some industries is relatively high. These industries occupy the dominant resources. In the development of resources, these industries can realize high profits through resource monopoly. In the country's economic development, monopoly industries rely on their own resources to dominate the market, there is no relatively fair competitive environment, employees in monopoly industries can therefore obtain higher income, and private enterprises employees still in a weak position in competition. There is no relative advantage, which results in a higher income gap.

\section{The Defects of Fiscal and Taxation Laws in Regulating Income Distribution}

The fiscal and taxation law is the legal basis for the state to acquire the ability to obtain resources, and at the same time it is designed to achieve the rational distribution of social resources and the balance of income. However, there are still some shortcomings in the fiscal and tax laws regulating income distribution.

\section{The design of taxation laws and regulations is not complete}

In view of the economic development, we should start to develop a variety of taxes in the context of diversified personal income to ensure the increase of tax revenue, and play a regulatory role in fiscal and tax laws. In terms of personal income tax. In China, the wages of some working-class employees are mainly taxed. The income sources of high-income people are more diversified. Because of the tax collection and management, high-income groups can adopt tax avoidance methods or means, thus reducing the income of high-income people. Regulating effect.

\section{There are some perfectities in the design of personal income tax}

In essence, fiscal and taxation laws levy part of the income of the rich who exceed the social average to compensate for the resource consumption of the rich in the process of getting rich and the exploitation of the surplus value of some people. Different people are different according to the consumption situation of the family and the expenditure. Therefore, it is not possible to adopt a one-size-fits-all approach to achieve the deduction standard for personal income tax. This unified approach can easily lead to income disparities between people and create a gap between rich and poor.

\section{The method of tax transfer payment is not scientific}

In China's fiscal and taxation management, mainly through the unified taxation, the central government allocates financial funds to the local government. In the collection and management of taxation, the central and local governments play a game. Generally, the places with more developed economies will pay relatively higher incomes to the central government. On the contrary, the regions with less developed economies will pay less tax credits. The central government supports the development of the local economy in terms of how much it pays in terms of transfer payments. However, regions with higher levels of local economic development will have more financial subsidies, and regions with lower levels of local economic development will have less financial support, which will not be able to drive the economy of underdeveloped regions. This type of tax transfer payment cannot achieve fairness in income adjustment.

\section{Lack of tax horizontal fiscal transfer payment system}

China's region is vast, and different regions have different levels of development in the process of economic development because of regional differences and policy support. These congenital unfair factors will cause the region to catch up with economically developed regions in the aftermath of development. China's fiscal and tax laws do not stipulate the transfer payment system between horizontal regions. Therefore, the inequality between regions can only be managed through central macro-control. Horizontal transfer payment is led by the central government. Although its enthusiasm has many effects, especially to achieve a certain degree of adjustment to the fairness of income distribution, there are many factors in the horizontal fiscal transfer payment, including 
between the two regions. The degree of difference, etc. will affect the construction of its formal system.

\section{Tax collection and management is not strong}

Tax collection and management will seriously affect the fairness of income distribution. In the tax revenue, it is necessary to fully grasp the tax source information. However, in the tax source information, the taxation department does not effectively communicate with other departments related to the residents' lives, and the taxation department cannot obtain such information about the residents. Affect the fairness of taxation.

\section{Improve Fiscal and Tax Laws and Promote Fair Income Distribution}

\section{Improve fiscal and tax laws and regulations, and establish a sound legal system}

The purpose of using fiscal and tax laws and regulations to achieve fair distribution of income is to establish a set of completed fiscal and taxation legal systems, focusing on the legal means to achieve the collection and management of taxes and the use of taxation. [6] At present, the basic principle of national income distribution can be determined through the formulation of the National Income Law. The principle of the relationship between various distribution ratios is determined through the income law, and the principles of distribution between regions and between urban and rural areas are carried out. confirm. In order to promote the fairness of income distribution, it is necessary to ensure that the central and local governments have clear standards for transfer payments and can follow relevant principles. To this end, it is necessary to formulate a relationship law between the central and local finances, a transfer payment relationship between the central and local finances, a horizontal transfer payment relationship between local finances, etc., and only ensure the institutionalization of various relationships to ensure income distribution. Rationalization. In order to ensure that each financial payment can play its best role, ensuring the fairness of society requires the formulation of public finance law, which requires reasonable adjustment of fiscal allocation, play the role of finance, and promote the equalization of public service expenditure.

\section{Improve the social security system and rationally adjust the tax distribution}

The social security system is to achieve the minimum guarantee for the residents' lives and to ensure that the people can have basic living conditions. Social security draws relevant resources from the state through the state tax revenue, and then through the state's fiscal expenditure to achieve social back-feeding. It is necessary to strengthen budget preparation and focus on the handling of the fiscal and budgetary relationship between the central and local governments. In the establishment of the social security system, we should create a comprehensive security system to provide a safe network for the people to ensure that the people can enjoy a basic living environment.

\section{Strengthening tax collection and management and strengthening tax regulation}

Although the taxation legal system has a certain degree of fairness and regulation, the role of the taxation legal system requires the implementation of taxation laws. The main body of tax collection should strengthen the supervision and enforcement of taxation to prevent the occurrence of tax evasion. The taxation department should also strengthen the sharing of information with various departments, promote cooperation with various departments, and collect more detailed tax information through cooperation to achieve tax collection and management. In the collection and management of taxation, the comprehensive quality of tax staff should also be strengthened, and information systems should be used to operate related taxation work and raise taxation levels. In the tax collection and management, it is necessary to strengthen the propaganda of the fiscal and taxation legal system and raise the taxpayer's awareness of taxation.

\section{Summary}

Fair income distribution is the most ideal state of social development. However, due to the advantages of resources and the level of human knowledge, there will inevitably present a hierarchical income pattern. The purpose of fiscal and tax laws and regulations is to adjust this pattern 
to a certain extent. Balanced state, guarantee the minimum living of the masses, and enable the society to achieve good governance.

\section{References}

[1] Xu Yan. Analysis of China's National Income Distribution Situation and Its Causes[J]. Reform and Strategy. 2012(10): 30-33.

[2] Liu Jianwen. Reform of Income Distribution and Innovation of Finance and Taxation Legal System[J].China Law.2011(05): 44-56

[3] Chen Tieshan. The function and limitations of fiscal and taxation policies to regulate the income distribution gap [J]. Taxation and Economy. 2011(04):106-108

[4] Tang Jianbo. Three Preconditions for Distributive Justice_- Revelations of Rawls, Hayek and Nozick[J]. philosophical dynamics. 2011(03):66-72

[5] [Meng Chun, Chen Changsheng. Reforming the fiscal and taxation system Optimizing the income distribution pattern[J]. China Finance.2011(06):28-29

[6] Fan Yi. Strengthening the Construction of Finance and Taxation Legal System and Promoting National Income Distribution Policy [J]. New Vision. 2011(04):67-70

[7] Shi Zhengbao, Li Tao, Wang Zhi. The Choice of China's Personal Income Tax System under the Perspective of Justice[J].Gansu Social Sciences.2011(04):80-83 